\title{
Threshold-based spraying decision programmes for the red spider mite Tetranychusmarianae on eggplant
}

\section{Authors: G. V. P. Reddy, R. Kikuchi, \& J. R. Bautista}

This is the peer reviewed version of the following article: as cited below, which has been published in final form at http://dx.doi.org/10.1111/jen.12007. This article may be used for noncommercial purposes in accordance with Wiley Terms and Conditions for Self-Archiving.

Reddy, G.V.P., R. Kikuchi, and J.R. Bautista. 2013. Threshold-based spraying decision programs for the red spider mite Tetranychus marianae on eggplant. Journal of Applied Entomology 137: 429-436. doi: 10.1111/jen.12007 


\title{
Threshold-based spraying decision programmes for the red spider mite Tetranychus marianae on eggplant
}

\author{
G. V. P. Reddy ${ }^{1}$, R. Kikuchi ${ }^{2}$ \& J. R. Bautista ${ }^{2}$ \\ 1 Western Triangle Agricultural Research Center Montana State University Conrad, MT, USA \\ 2 Western Pacific Tropical Research Center College of Natural and Applied Sciences University of Guam Mangilao, Guam, USA
}

\begin{abstract}
The red spider mite, Tetranychus marianae McGregor (Acari: Tetranychi-dae), has been an important pest of eggplant Solanum melongena L. (Solan-aceae) and other vegetables in the Mariana Islands. The damage due to T. marianae has been severe and caused huge economic losses. Because no threshold levels are available for $T$. marianae, many growers are applying up to 12 chemical applications per eggplant cropping period. This is not only expensive, but also results in lower yields because of extensive foliar damage and development of resistance in mites to chemicals. To diminish the calendarbased chemical applications and to preclude damage to foli-age and fruit quality, this study was undertaken for the development of a threshold level for optimum timing of chemical applications for $T$. mari-anae. In the direction of this aim, an attempt was made to generate differ-ent threshold levels by applying chemical spray (Sun-spray 6E, $5 \mathrm{ml} / \mathrm{l}$ ) within $12 \mathrm{~h}$ after reaching the threshold levels at 2, 4, 6, 8 and 10 mites/leaf, as well as current recommended calendar-based sprays and non-sprayed control in a replicated block design for the dry and wet seasons of 2010 at two locations (Yigo and Inaranjan) in Guam (USA). Based on T. marianae-infested leaves, incidence of T. marianae and yield levels, the plots sprayed at 2 or 4 mites/leaf in the dry season and 2-8 mites/leaf dur-ing the wet season had significantly lower leaf damage and incidence of T. marianae compared with a greater number of mites/ leaf in calendar-based sprays and control plots. At the greater threshold levels, the mean yield was significantly reduced in comparison with the mean yield obtained when plots were sprayed at a threshold of 2-8 mites/leaf. There-fore, it is concluded that the optimum threshold chemical spray for T. marianae on eggplant is 4 mites/leaf during the dry season and 8 mites/leaf in the wet season.
\end{abstract}

\section{Introduction}

The red spider mite, Tetranychus marianae McGregor (Acari: Tetranychidae), is considered a potentially highly destructive pest and, if established in commercial fields, will add considerably to production costs (Oatman et al. 1967). This mite species is a major pest of vegetables (eggplant, tomato, cucumbers, pepper, etc.), and even a small number of T. marianae on plants can cause severe damage as they are a year-round pest (Reddy et al. 2011). The mite causes serious damage in the Marianas and Florida on Solanaceous plants throughout the year (Denmark 1970). This mite species was first recorded on Passiflora foetida L. (Passifloraceae) in Mt. Lassso, Tinian (The Common Wealth of the Mariana Islands), in 1946 (McGregor 1950). It is widespread in the Pacific islands and also found in the West Indies, Bahamas, Southern Florida, Nicaragua, Argentina, Brazil and South-East Asia (Denmark 1970; de Moraes et al. 
1987). Tetranychus marianae prefers to feed and thrives on Solanaceous plants, but it has also been reported on numerous other plants (Reddy et al. 2011).

Although no information is available on the damage potential and biology of T. marianae on eggplant, Solanum melongena (Solanaceae), Wene (1956) observed that heavily infested tomato leaves became yellowish-green to yellowish-brown. The author further reported that the feeding of $T$. marianae caused a silvering on the shoulder of the fruit, and this silvery area became russet brown in appearance. Denmark (1970) reported that the mites caused tomato leaves to become chlorotic and curl. Tests of the effect of T. marianae on tomato, Irish potato, bell pepper and eggplant in a glasshouse showed that potato and eggplant were virtually destroyed within 3 weeks after being infested with 20 mature females on each plant (Oatman et al. 1967).

The biology of T. marianae was studied on yellow passion fruit (Passiflora edulis Sims f. flavicarpa Deg.) by Noronha (2006). The mite is usually found on the abaxial surface of leaves with the presence of web formation (Ochoa et al. 1994). The longevity of T. marianae females was reported to be close to 30 days (Bonato and Gutierrez 1999). Female T. marianae can produce offspring parthenogenetically (Davis 1969). Eggs are deposited singly on the lower surface along or near the leaf midrib or veins. Feeding perforations on eggplant leaves by T. marianae become chlorotic and are visible as whitish to yellowish stipplings or dots at the upper surface of the leaf (Mata 1984). Under substantial infestation, the chlorotic areas may amalgamate so that leaves eventually turn yellow and can drop prematurely (Reddy et al. 2011).

As no damage threshold levels have been developed for T. marianae, some growers in the Mariana Islands are applying 10-12 chemical sprays per cropping period, often leading to extensive foliar damage and resulting in lower yield levels because of the development of resistance of mites to the chemicals. Most growers in the Mariana Islands are unaware of the benefits of the threshold levels or the adverse effects of chemical sprays on beneficial organisms (Biddinger et al. 2009). The use of pesticides in the Pacific region increased dramatically in the recent past due to the increase in T. marianae. There has been no record of any predatory mites or any other biological control being used in the region. Although both economic injury level (EIL) and an economic threshold level (ETL) or action threshold (AT) are important and help in reducing the judicious use of chemical applications (Maoz et al. 2011), extensive field studies for several consecutive years is necessary. However, the current study was aimed at developing threshold levels for T. marianae on eggplant in order to provide a more immediate solution to growers to reduce the number of chemical applications required for the control of the pest.

\section{Materials and Methods}

\section{Eggplant seedlings}

The eggplant seeds of Pingtung Long variety (KnownYou Seed, Co., Ltd., Kaohsiung, Taiwan) were sown in trays $(40 \times 30 \mathrm{~cm})$ and raised in a nursery in a shade house $\left(30-32^{\circ} \mathrm{C}, 60-80 \% \mathrm{RH}, 14: 10\right.$-h light/ dark photoperiod). The seedlings were grown for 40 days.

\section{Study sites}

Experiments were performed in two locations of the University of Guam Agricultural Experiment Station, Yigo $\left(13^{\circ} 31.930^{\prime} \mathrm{N}, 144^{\circ} 52.351^{\prime} \mathrm{E}\right)$ and Inarajan $\left(13^{\circ} 61.963^{\prime} \mathrm{N}, 144^{\circ} 45.353^{\prime} \mathrm{E}\right)$. The first trial was carried out during the dry season (February-June, 2010) at both Yigo and Inarajan, and the second identical trial was carried out at the same locations during the wet season (August-December 2010). The treatment plots were $8 \mathrm{~m} \times 8 \mathrm{~m}$ in a factorial design and separated from other plots by $1.0-\mathrm{m}$ buffer zones intended to prevent spray drift. Forty-day-old eggplant seedlings were transplanted at a distance of $75 \mathrm{~cm}$ between rows and $50 \mathrm{~cm}$ between plants in the row. Three replicates of each of 10 treatments produced a total of 30 plots. Each plot consisted of 10 rows of 15 eggplant plants, for a total of 150 plants per plot. The total area of the experimental eggplant field was $2900 \mathrm{~m}^{2}$ (0.29 ha) at each site. All the fertilizer applications were followed according to Schlub and Yudin (2002).

\section{Chemical treatment}

For treatment applications T1-T5 based on T. marianae threshold levels, an application of Sun-spray $6 \mathrm{E}$ (Sunoco, Inc R\&M, Philadelphia; active ingredients: refined petroleum distillate: $98.8 \mathrm{wt} \%+$ emulsifier: $1.2 \mathrm{wt} \%$ ) at the rate of $5 \mathrm{ml} / \mathrm{l}$ was sprayed within $12 \mathrm{~h}$ after reaching mean threshold levels of 2, 4, 6, 8 or 10 mites/leaf. The Sun-spray chemical was chosen for the present study as it is environmentally friendly and is significantly proven to be effective against spider mites (Lancaster et al. 2002). For the calendarbased chemical treatments, spray [Sun-spray 6E 
$(5 \mathrm{ml} / \mathrm{l})$ ] was applied as shown in the treatments T6-T9. This spraying schedule was usually performed by growers. No chemical treatment was applied in T10 (control, three replications).

T1: Threshold-based chemical sprays (TCS) (mean of 2 mites/leaf);

T2: TCS (mean of 4 mites/leaf);

T3: TCS (mean of 6 mites/leaf);

T4: TCS (mean of 8 mites/leaf);

T5: TCS (mean of 10 mites/leaf);

T6: calendar-based spray schedule (CSS) (10 days after transplanting (DAT)): 10, 20, 30, 40, 50, 60, 70, 80, 90, 100, 110 and 120;

T7: CCS: (15 DAT): 15, 30, 45, 60, 75, 90, 105 and 120;

T8: CCS: (20 DAT): 20, 40, 60, 80, 100 and 120;

T9: CCS: (25 DAT): 25, 50, 75, 100 and 125; and

T10: Control (no spray).

The days of chemical application in each treatment are shown in table 1 . The amount of solution sprayed per application was $95 \mathrm{l} /$ ha for small plants (up to 45 DAT) and 190.0 1/ha for larger ones (45 DAT until harvest). All the chemicals were applied with motorized backpack sprayers (Solo Brand; Forestry Suppliers, Jackson, MS). The sprayer was equipped with an adjustable, flat spray, hollow cone and jet stream nozzle, and pressure was calibrated to deliver 20 gpa at 45 psi.

\section{Sampling method}

To determine the mite population level, ten plants were selected randomly per plot. For each plant, three leaves were chosen randomly: one per top, middle and bottom of the plant. On the underside of each of these leaves, the number of mites present was counted using a magnifying lens. The counts were made at weekly intervals. Similarly, the number of infested leaves by T. marianae per plot was recorded out of the 30 leaves counted in each plot. The eggplant were harvested when they were ready and the yield was recorded for each treatment plot. The data were averaged and expressed as per cent of infested leaves and yield per hectare.

\section{Statistical analysis}

Data for the number of infested leaves on 10 plants per plot and overall yield levels in different treatments were analysed using repeated-measures ANovA $(\mathrm{P}<0.05)$ over multiple dates, and differences between treatment means were compared using
Tukey's HSD test. All statistical analyses were carried out using SAS version 9.3 (SAS Institute 2009). The $5 \%$ level of significance was used for all analyses.

\section{Results}

The results indicated that mean percentages of mite-infested leaves and the population of T. marianae at both the locations are higher when threshold levels and the number of chemical sprays were advanced (tables 2 and 3). During the dry season, T. marianae and infested leaves were significantly fewer $\left(\mathrm{F}_{9,29}=54.9, \mathrm{P}<0.05\right)$ in $\mathrm{Tl}(2$ mites/leaf $)$ and T2 (4 mites/leaf) compared to other treatments with higher threshold levels. However, a significant difference was not observed between the treatments of 2 mites/leaf and 4 mites/leaf. For the period of the wet season, T. marianae and infested leaves were significantly fewer $\left(\mathrm{F}_{3,29}=89.4, \mathrm{P}<0.05\right)$ in T1 (2 mites/leaf) through T4 (8 mites/leaf) compared to $\mathrm{T} 5$ (10 mites/leaf). In both the dry and wet seasons, the calendar-based treatments T6-T8 (10-20 DAT) recorded significantly fewer $\left(\mathrm{F}_{9,29}=\right.$ 121.5, $\mathrm{P}<0.05)$ levels of T. marianae and infested leaves than T9 (25 DAT). Significantly higher $\left(\mathrm{F}_{9,29}=101.6, \mathrm{P}<0.05\right)$ levels of $T$. marianae and infested leaves were recorded in control treatments compared to all other treatments in both locations and wet and dry seasons. The overall data from the threshold and calendar treatments indicated that the mean number of $T$. marianae and infested leaves was significantly fewer $\left(\mathrm{F}_{11,29}=112.6, \quad \mathrm{P}<0.05\right)$ in threshold treatments than in calendar-based treatments.

The results for marketable eggplant yield levels were reflected by the number of $T$. marianae-infested leaves (fig 1). During the dry season, the yield levels were significantly higher $\left(\mathrm{F}_{9,29}=54.9, \mathrm{P}<0.05\right)$ in T1 (2 mites/leaf) and T2 (4 mites/leaf) compared to T3-T5 (6-10 mites/leaf) in both locations. However, in the wet season, the yield levels were significantly higher $\left(\mathrm{F}_{9,29}=110.3, \mathrm{P}<0.05\right)$ in $\mathrm{T} 1-\mathrm{T} 4$ compared to T5. In both the dry and wet seasons, the calendar-based treatments T6-T8 (10-20 DAT) recorded significantly higher $\left(\mathrm{F}_{9,29}=87.4, \quad \mathrm{P}<0.05\right)$ yields than T9 (25 DAT). The control (no spray) plots yielded significantly lower marketable yields (10.412.2 tons/ha) as an average for both the seasons and locations. The average overall yield from the threshold and calendar treatments indicated that the yield levels were significantly higher $\left(\mathrm{F}_{14,29}=78.6\right.$, $\mathrm{P}<0.05)$ in threshold treatments than in calendarbased treatments. 


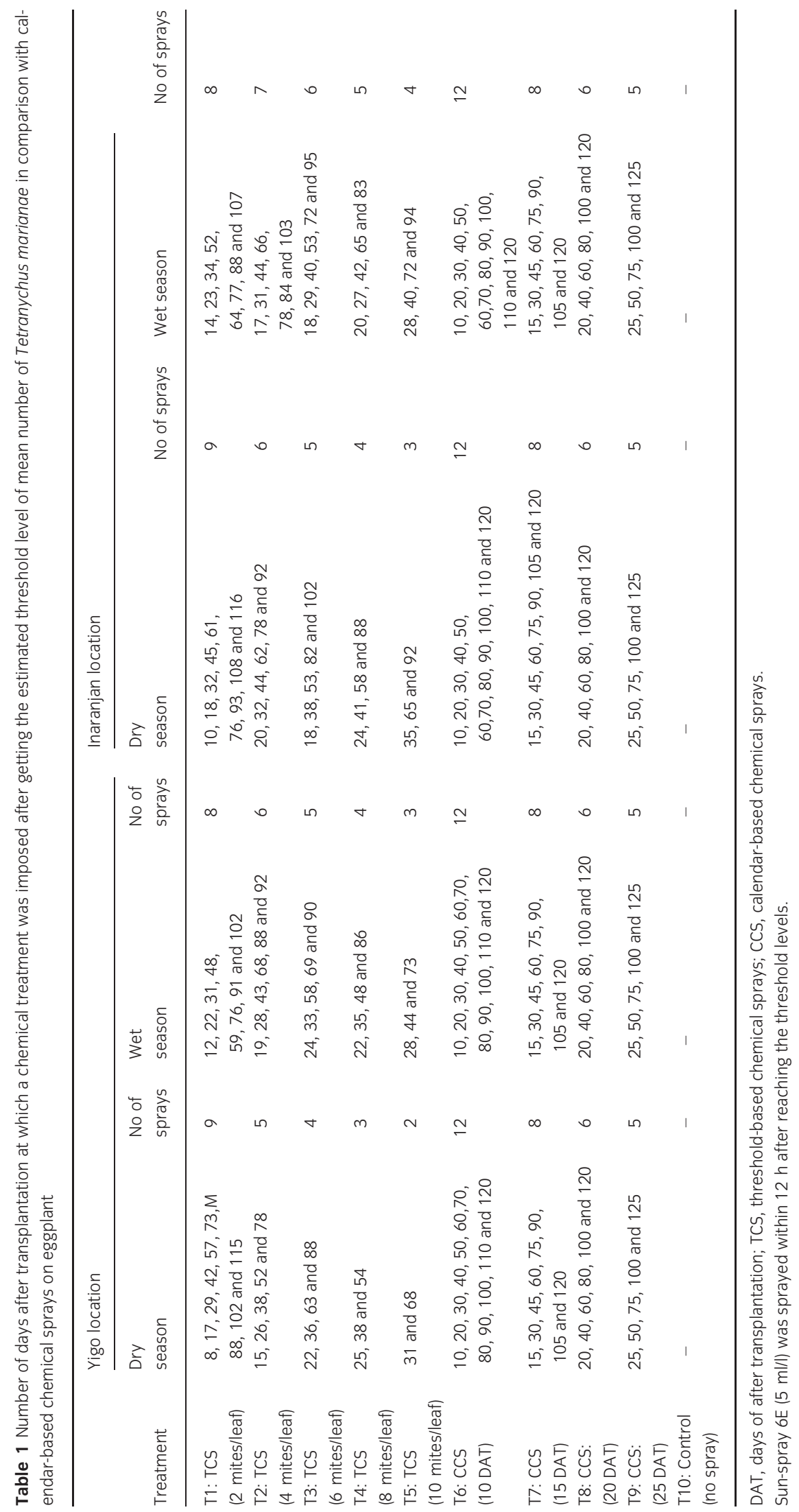


Table 2 Percentage of infested leaves resulting from Tetranychus marianae in different treatments of TCS vs. calendar-based chemical sprays on eggplant grown in dry and wet seasons

Table 3 Mean number of Tetranychus marianae in different treatments of TCS vs. calendar-based chemical sprays on eggplant grown in dry and wet seasons

\begin{tabular}{|c|c|c|c|c|}
\hline \multirow[b]{3}{*}{ Treatment } & \multicolumn{4}{|c|}{ Mean \pm SE per cent infested leaves } \\
\hline & \multicolumn{2}{|l|}{ Yigo location } & \multicolumn{2}{|c|}{ Inaranjan location } \\
\hline & Dry season & Wet season & Dry season & Wet season \\
\hline T1: TCS (2 mites/leaf) & $0.2 \pm 0.1 a$ & $0.1 \pm 0.1 \mathrm{a}$ & $0.5 \pm 0.2 \mathrm{a}$ & $0.0 \pm 0.0 a$ \\
\hline T2: TCS (4 mites/leaf) & $0.5 \pm 0.2 a$ & $0.2 \pm 0.1 a$ & $1.5 \pm 1.2 \mathrm{a}$ & $0.2 \pm 0.1 \mathrm{a}$ \\
\hline T3: TCS (6 mites/leaf) & $15.0 \pm 1.5 b$ & $1.5 \pm 0.3 a$ & $18.0 \pm 2.1 b$ & $1.5 \pm 0.5 a$ \\
\hline T4: TCS (8 mites/leaf) & $19.5 \pm 0.4 b$ & $2.0 \pm 1.1 a$ & $22.0 \pm 1.2 b$ & $2.0 \pm 1.2 \mathrm{a}$ \\
\hline T5: TCS (10 mites/leaf) & $32.0 \pm 1.8 c$ & $28.0 \pm 2.4 b$ & $43.5 \pm 2.3 c$ & $22.0 \pm 2.3 b$ \\
\hline T6: CCS (10 DAT) & $0.5 \pm 0.2 \mathrm{a}$ & $1.5 \pm 0.8 \mathrm{a}$ & $1.0 \pm 0.2 \mathrm{a}$ & $1.0 \pm 0.0 \mathrm{a}$ \\
\hline T7: CCS (15 DAT) & $5.0 \pm 0.1 a$ & $4.5 \pm 0.8 a$ & $5.0 \pm 0.4 a$ & $6.0 \pm 0.2 a$ \\
\hline T8: CCS: (20 DAT) & $8.0 \pm 0.2 a$ & $8.5 \pm 0.6 a$ & $7.5 \pm 1.3 a$ & $9.0 \pm 1.0 \mathrm{a}$ \\
\hline T9: CCS: (25 DAT) & $22.0 \pm 0.4 b$ & $26.0 \pm 2.1 b$ & $24.5 \pm 2.2 b$ & $20.0 \pm 1.8 b$ \\
\hline T10: Control (no spray) & $96.5 \pm 1.3 d$ & $82.0 \pm 3.4 c$ & $98.0 \pm 3.2 d$ & $84.0 \pm 2.4 \mathrm{C}$ \\
\hline
\end{tabular}

DAT, days of after transplantation; TCS, threshold-based chemical sprays; CCS, calendar-based chemical sprays.

Means within the same column followed by the same letter are not significantly different $P>0.05$ (repeated-measures ANovA, Tukey's HSD). Each value represents the mean ( \pm SE) of three replications. The mean number of infested leaves by $T$. marianae per plot was recorded out of the 30 leaves counted in each plot.

\begin{tabular}{|c|c|c|c|c|}
\hline \multirow[b]{3}{*}{ Treatment } & \multicolumn{4}{|c|}{ Mean \pm SE number of $T$. marianae/leaf } \\
\hline & \multicolumn{2}{|l|}{ Yigo location } & \multicolumn{2}{|c|}{ Inaranjan location } \\
\hline & Dry season & Wet season & Dry season & Wet season \\
\hline T1: TCS (2 mites/leaf) & $1.8 \pm 0.4 a$ & $1.6 \pm 0.5 a$ & $1.9 \pm 0.7 a$ & $1.7 \pm 0.6 a$ \\
\hline T2: TCS (4 mites/leaf) & $3.5 \pm 1.1 a$ & $3.4 \pm 1.3 a$ & $3.8 \pm 1.2 \mathrm{a}$ & $3.5 \pm 1.2 \mathrm{a}$ \\
\hline T3: TCS (6 mites/leaf) & $30.4 \pm 2.8 b$ & $5.8 \pm 0.8 \mathrm{a}$ & $48.5 \pm 4.3 b$ & $5.7 \pm 2.2 a$ \\
\hline T4: TCS (8 mites/leaf) & $46.3 \pm 3.2 b$ & $7.5 \pm 2.1 \mathrm{a}$ & $51.7 \pm 2.6 b$ & $7.8 \pm 3.3 a$ \\
\hline T5: TCS (10 mites/leaf) & $32.0 \pm 2.7 \mathrm{c}$ & $28.0 \pm 3.5 b$ & $43.5 \pm 3.7 c$ & $32.5 \pm 2.3 b$ \\
\hline T6: CCS (10 DAT) & $8.5 \pm 1.7 a$ & $10.6 \pm 1.7 a$ & $15.6 \pm 2.5 a$ & $11.6 \pm 3.1 \mathrm{a}$ \\
\hline T7: CCS (15 DAT) & $14.3 \pm 2.4 a$ & $11.2 \pm 2.2 \mathrm{a}$ & $17.2 \pm 3.1 \mathrm{a}$ & $13.4 \pm 2.7 a$ \\
\hline T8: CCS: (20 DAT) & $18.8 \pm 1.8 \mathrm{a}$ & $14.5 \pm 2.6 a$ & $18.4 \pm 3.2 \mathrm{a}$ & $15.8 \pm 1.5 a$ \\
\hline T9: CCS: (25 DAT) & $48.6 \pm 4.1 b$ & $36.0 \pm 4.4 b$ & $54.8 \pm 6.8 b$ & $40.6 \pm 4.6 b$ \\
\hline T10: Control (no spray) & $630 \pm 12.8 d$ & $493 \pm 12.2 c$ & $735 \pm 11.3 d$ & $527 \pm 8.8 c$ \\
\hline
\end{tabular}

DAT, days of after transplantation; TCS, threshold-based chemical sprays; CCS, calendar-based chemical sprays.

Means within the same column followed by the same letter are not significantly different $P>0.05$ (repeated-measures ANovA, Tukey's HSD). Each value represents the mean $( \pm S E)$ of three replications. The mean number of $T$. marianae per plot was recorded out of the 30 leaves counted in each plot.

\section{Discussion}

Using TCS to replace calendar-based chemical sprays to better control pests has been considered a top priority for sustainable agriculture. This study is a helpful addition which demonstrates that calendar-based chemical sprays are not a desirable pest control strategy for growers in terms of safety and pesticide residue problem in food products particularly vegetables.
Threshold-based spraying decision programmes are an important option in integrated pest management (Silvie et al. 2001). The integration in farmers' practices of calendar-based spraying decisions for spider mites has been followed since two decades in many parts of the world (Reddy and Guerrero 2001). Calendarbased programmes have been followed by growers to reduce risk because of a lack of research information for many pests, particularly for spider mites. 

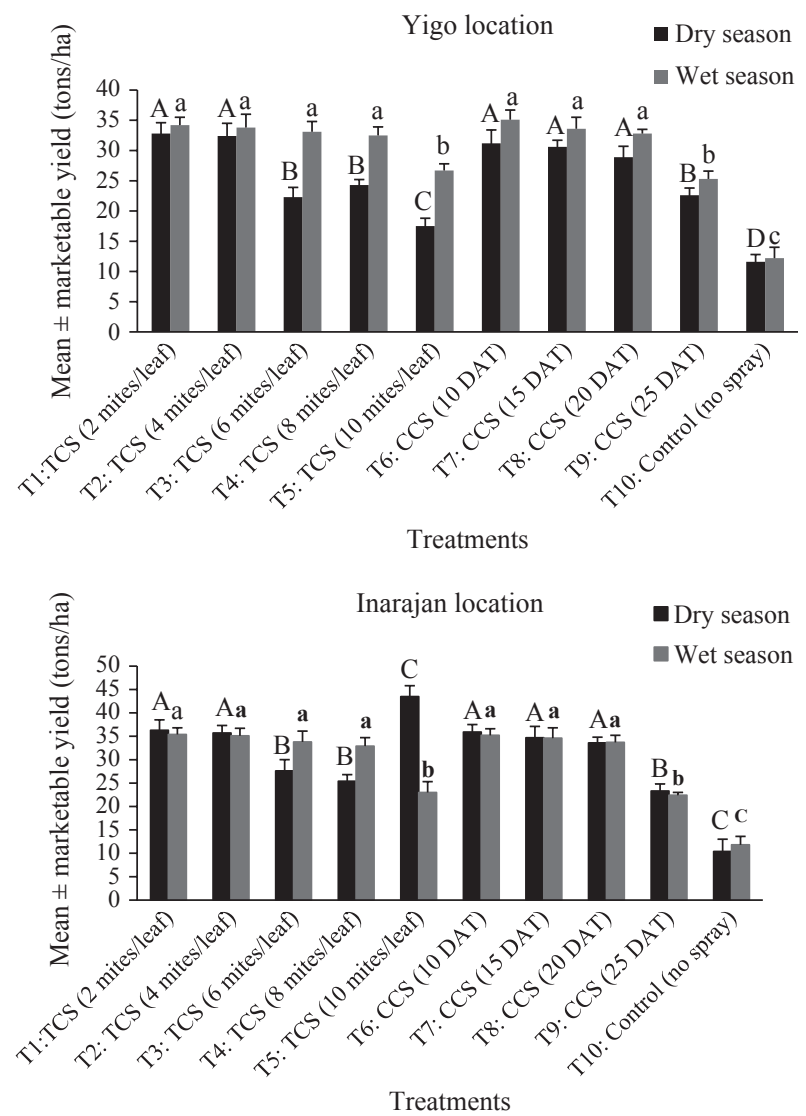

Fig. 1 Marketable yield (tones/ha) of eggplant after chemical application in different treatments of TCS vs. calendar-based chemical sprays on eggplant grown in dry and wet seasons. Different letters above the bars indicate significant differences $P>0.05$ (repeated-measures ANOVA, Tukey'S HSD). Each value represents the mean $( \pm \mathrm{SE})$ of three replications. DAT, days of after transplantation; TCS, threshold-based chemical sprays; CCS, calendar-based chemical spray.

As of today, this is the first time that a thresholdbased chemical spray programme has been reported for T. marianae on eggplant. However, damage threshold levels have been determined and reported for other mites. For example, Tetranychus pacificus and T. turkestani Ugarvo \& Nikolski on rose Rosa hybrid L. (Rosales: Rosaceae) (Karlik et al. 1995) and Tetranychus ludeni Koch on Impatiens wallerana Hook.f. (Ericales: Balsaminaceae) (Alatawi et al. 2007) have been studied. In the present study, threshold-based spray and fewer chemical sprays reduced the leaf damage and incidence of T. marianae when compared to calendar-based chemical sprays and control (no spray) treatments. It is interesting to note that the treatments with 2 or 4 mites/leaf had significantly lower incidence of T. marianae and higher yield levels recorded during the tests in the dry season. The threshold treatment with a mean of 2 mites/leaf requires nine chemical sprays, while only five sprays are necessary for the threshold level of 4 mites/leaf. This way, four chemical sprays can be avoided for the control of T. marianae by choosing 4 mites/leaf. Because no significant difference was observed between these two threshold treatments in terms of leaf damage and yield levels, it is recommended to use 4 mites/leaf as a threshold level for $T$. marianae during the dry season. In the same way, the treatments with 2-8 mites/leaf during the wet season had significantly lower leaf damage and higher yield levels than the control (no spray) treatment and some of the calendar-based chemical sprays. The threshold treatments with means of 2, 4, 6 and 8 mites/leaf require 8, 6, 5, and 4 sprays, respectively. Again, no significant difference was observed between these threshold levels in terms of leaf damage and marketable yield levels. Based on these two season (wet and dry) trial results, therefore, it is recommended to use 8 mites/leaf as a threshold level for T. marianae during the wet season. Implementing this approach, up to four sprays can be avoided for the control of T. marianae during the wet season.

The most important point here is to note that different threshold levels are required for T. marianae on eggplant during the dry and wet seasons. This is because of the population fluctuation, and it could be argued that, during the dry season, the population's build-up is higher than in the wet season. Our findings corroborate with Denmark (1970), who reported that $T$. marianae has a high biotic potential and often reaches high populations in dry, warm weather, at which time uncontrolled populations occur. Our results are somewhat different with Bostanian et al. (2003) who reported that it would be possible to reduce the number of acaricide applications as the eggplant tolerates a high density of $T$. urticae without any decrease in yield. In this respect, they proposed 700 mites per leaf as a tentative empirical action threshold based on their results. According to these authors, however, as this preliminary threshold may be attained during adverse weather conditions and it may not be possible to enter and treat the field promptly, a 600 mite per leaf action threshold may be more appropriate. Thus, a buffer of 100 mites per leaf would provide the time span for the return of better weather conditions for an acaricide treatment (Bostanian et al. 2003). Also, Beers and Hull (1990) and Palevsky et al. (1996) found that high mite densities (450-1000) of Panonychus ulmi (Koch) occurring in mid-season on apples can reduce the fruit weight in the year of mite damage and can decrease the number of fruit in the following season. Weihrauch (2005) 
noticed that although T. urticae infestation of cones from untreated hops, Humulus lupulus (Cannabaceae), was significantly higher than acaricide-treated plants in 27 of the 36 cases, in only one instance did that cause economic loss. T. urticae infestation levels of about 90 mites per leaf are tolerable at harvest time with little or no risk of causing economic loss to hop growers.

Existing synthetic chemicals are still being used in parts of the world to control mite incidence on various crops. Dicofol is one of the acaricides that traditionally are used to control the spider mites on various crop plants in several countries (Dutcher 2007). However, dicofol resistance in mites has been a growing problem, and it developed resistance to mite species particularly after recurrent applications (Singh 2010). While the label on carbaryl does list mites, the product is well known and actually to induce mite population after repeated applications. Many farmers in Micronesia are required to use repeated applications because of the ineffectiveness of these chemicals and the eventual mite population build-up. In addition, carbaryl is known to cause mite populations to flare and become carbaryl resistant (Shaw and Wallis 2008). On the other hand, horticultural oils' (Sun-spray ultra-fine oil) attractive substitutes to traditional pesticides, as they are effective in controlling pests while at the same time conserving beneficial arthropods (Miller 1997). This is a highly refined horticultural spray oil concentrate for insect, mite and disease pest management and reported to be effective against mites (Knapp et al. 2001). However, this chemical needs to be special ordered and imported to the islands, and thereby, it is often expensive. Thus, the research information generated from the present study on the optimizing threshold levels can be useful to the eggplant growers on the use of Sun-spray in order to save money on a safer product.

While T. marianae damage can still be prevented by modern acaricide applications to some extent, it is expected that the excessive use of these chemical applications will eventually lead to resistance development and subsequent pest outbreaks (van de Vrie 1985; Penman and Chapman 1988). Adopting the economic threshold levels established in the present study could help to reduce pesticide applications against $T$. marianae, with the resultant selection for pest resistance, adverse effects to biological control agents, and harm to human health and the environment. Because T. marianae is an economically detrimental pest on eggplant in the Mariana Islands, the research information generated from the present study is important and should be disseminated to the public and eggplant growers. The threshold levels of 4 and 8 mites/leaf in the dry and wet seasons, respectively, can be adopted for the control of T. marianae on eggplant. Also, the threshold levels found in this study can be used, as suggested by Palevsky et al. (2007), to assess the degree of success of integrated control programmes, such as the conservation and augmentation of mites' natural enemies.

\section{Acknowledgements}

This project was supported by FY 2009 United States Environmental Protection Agency (USEPA) Strategic Agriculture Initiative/Food Quality Protection Act (FQPA) Grant Agreement \# X8-00T32301-0 and FY 2010 Pacific Islands Area Conservation Innovation Grants (PIA-CIG) Program, Grant Agreement No. 699251-10-880, The Natural Resources Conservation Service (NRCS)-United States Department of Agriculture. The USDA is an equal opportunity provider and employer.

\section{Conflict of interest}

The authors declare no conflict of interest.

\section{References}

Alatawi FJ, Margolies DC, Nechols JR, 2007. Aesthetic damage thresholds for twospotted spider mites (Acari: Tetranychidae) on impatiens: effect of plant age and level of infestation. J. Econ. Entomol. 100, 1904-1909.

Beers EH, Hull LA, 1990. Timing of mite injury affects the bloom and fruit development of apple. J. Econ. Entomol. 83, 547-551.

Biddinger DJ, Weber DC, Hull LA, 2009. Coccinellidae as predators of mites: stethorini in biological control. Biol. Control 51, 268-283.

Bonato O, Gutierrez J, 1999. Effect of mating status on the fecundity and longevity of four spider mite species (Acari: Tetranychidae). Exp. Appl. Acarol. 23, 623-632.

Bostanian NJ, Trudeau M, Lasnier J, 2003. Management of the two-spotted spider mite, Tetranychus urticae (acari: Tetranychidae) in eggplant fields. Phytoprotection 84, $1-8$.

Davis JJ, 1969. A note on cuticular lobes of Tetranychus marianae McGregor (Acarina; Tetranychidae) from Papua. J. Aust. Entomol. Soc. 8, 112.

Denmark HA, 1970. The Mariana mite, Tetranychus marianae McGregor, in Florida (Tetranychidae). Florida Dept. Agric. Cons. Serv. Div. Plant Ind., Entomol Circ. 99, 1. Dutcher JD, 2007. A review of resurgence and replacement causing pest outbreaks in IPM. In: General 
concepts in integrated pest and diseases management. Ed. by Ciancio A, Mukerji KG, Springer, Dordrecht, The Netherlands, 27-43.

Karlik JF, Goodell PB, Osteen GW, 1995. Sampling and treatment threshold for spider mite management in field grown Rose plants. HortScience 30, 1268-1270.

Knapp JC, Nigg HN, Anderson HE, 2001. Update on petroleum spray oil for the citrus rust mite control. Proc. Fla. State Hort. Soc. 114, 46-51.

Lancaster AL, Deyton DE, Sams CE, Cummins JC, Pless CD, Fare DC, 2002. Soybean oil controls two-spotted spider mites on burning bush. J. Environ. Hortic. 20, 86-92.

Maoz Y, Gal S, Zilberstein M, Izhar Y, Alchanatis V, Coll M, Palevsky E, 2011. Determining an economic injury level for the persea mite, Oligonychus perseae, a new pest of avocado in Israel. Entomol. Exp. Appl. 138, 110-116.

Mata IC, 1984. Biology of sweetpotato spider mite, Tetranychus mariannae McGregor (Tetranychidae: Acarina). Unpublished BS Thesis, Visayas State College of Agriculture, Baybay, Leyte, Philippines.

McGregor EA, 1950. Mites of the family Tetranychidae. Am. Midland Nat. 44, 257-420.

Miller F, 1997. An evolution of repetitive summer horticultural oil sprays on selected woody landscape plants. J. Environ. Hortic. 15, 102-108.

de Moraes GJ, McMurtry JA, Baker EA, 1987. Redescription and distribution of the spider mites Tetranychus evansi and T. marianae. Acarologia 28, 33-343.

Noronha ACS, 2006. Biological aspects of Tetranychus marianae McGregor (Acari, Tetranychidae) reared on yellow passion fruit (Passiflora edulis Sims f. flavicarpa Deg.) leaves. Rev. Brasil. de Zool. 23, 404-407.

Oatman ER, Fleschner O, McMurtry JA, 1967. New spider mite poses threat to California's solanaceous crops. California Agric. 21, 10-12.

Ochoa R, Aguilar H, Vargas C, 1994. Phytophagous mites of Central America: an illustrated guide. Turrialba, Catie 234p.

Palevsky E, Oppenheim D, Reuveny H, Gerson U, 1996. Impact of European red mite on golden delicious and Oregon Spur apples in Israel. Exp. Appl. Acarol. 20, 343-354.
Palevsky E, Maoz Y, Gal S, Argov Y, Zilberstein M, Noy M, Izhar Y, Alchanatis V, 2007. Developing an action threshold for the Persea mite on Avocado. Proceedings VI World Avocado Congress (Actas VI Congreso Mundial del Aguacate), Viña Del Mar, Chile, 12-16 Nov. 2007.

Penman DR, Chapman RB, 1988. Pesticide-induced mite outbreaks: pyrethroids and spider mites. Exp. Appl. Acarol. 4, 265-276.

Reddy GVP, Guerrero A, 2001. Optimum timing of insecticide applications against diamondback moth, Plutella xylostella in cole crops using threshold catches in sex pheromone traps. Pest Manag. Sci. 57, 90-94.

Reddy GVP, Kikuchi R, Remolona JE, 2011. New mite species associated with certain plant species from Guam. J. Entomol. Acarol. Res. Ser. II, 43, 41-46.

SAS Institute Inc., 2009. SAS/STAT user's guide, release 9.3. SAS Institute, Cary, NC.

Schlub R, Yudin L, 2002. Eggplant, Pepper, and Tomato Production Guide for Guam, Guam Cooperative Extension, University of Guam, 188p.

Shaw PW, Wallis DR, 2008. Biocontrol of pests in apples under integrated fruit production. N.Z. Plant Prot. 61, 333-337.

Silvie P, Deguine JP, Nibouche S, Michel B, Vaissayre M, 2001. Potential of threshold-based interventions for cotton pest control by small farmers in West Africa. Crop. Prot. 20, 297-301.

Singh S, 2010. Resistance development in mites to plant protection chemicals: a review. J. Entomol. Res. 34, 117-123.

van de Vrie M, 1985. Control of Tetranychidae in crops Greenhouse ornamentals. In: Spider mites - their biology, natural enemies and control, Vol. 1B. Ed. by Helle W, Sabelis MW, Elsevier Science, Amsterdam, The Netherlands, 273-283.

Weihrauch F, 2005. Evaluation of a damage threshold for two-spotted spider mites, Tetranychus urticae koch (Acari: Tetranychidae), in hop culture. Ann. Appl. Biol. 146, 501-509.

Wene GP, 1956. Tetranychus marianae McG, a new pest of tomatoes. J. Econ. Entomol. 49, 712. 